\title{
Diabetic Gastroparesis: Therapeutic Options
}

\author{
Uazman Alam · Omar Asghar · Rayaz Ahmed Malik
}

Received: May 28, 2010 / Published online: October 26, 2010

(c) The Author(s) 2010. This article is published with open access at Springerlink.com

\section{ABSTRACT}

Gastroparesis is a condition characterized by delayed gastric emptying and the most common known underlying cause is diabetes mellitus. Symptoms include nausea, vomiting, abdominal fullness, and early satiety, which impact to varying degrees on the patient's quality of life. Symptoms and deficits do not necessarily relate to each other, hence despite significant abnormalities in gastric emptying, some individuals have only minimal symptoms and, conversely, severe symptoms do not always relate to measures of gastric emptying. Prokinetic agents such as metoclopramide, domperidone, and erythromycin enhance gastric motility and have remained the mainstay of treatment for several decades, despite unwanted side effects and numerous drug interactions. Mechanical therapies such as endoscopic pyloric botulinum toxin injection, gastric electrical stimulation, and gastrostomy or jejunostomy are used in

Uazman Alam · Omar Asghar · Rayaz Ahmed Malik ( $\bowtie)$ Department of Cardiovascular Sciences, University of Manchester, Core Technology Facility (3rd Floor), Grafton Street, Manchester, M13 9NT, UK.

Email: Rayaz.a.malik@manchester.ac.uk intractable diabetic gastroparesis (DG), refractory to prokinetic therapies. Mitemcinal and TZP-101 are novel investigational motilin receptor and ghrelin agonists, respectively, and show promise in the treatment of DG. The aim of this review is to provide an update on prokinetic and mechanical therapies in the treatment of DG.

Keywords: diabetic gastroparesis; gastric electrical stimulation; ghrelin; mechanical therapy; prokinetic therapy

\section{INTRODUCTION}

Gastroparesis is characterized by a failure of normal gastric motility and emptying. The delay in gastric emptying leads to considerable morbidity due to nausea, vomiting, anorexia, and stomach fullness. Both type 1 and 2 diabetes mellitus are frequently associated with abnormal gastric motility, ${ }^{1,2}$ and are a recognized cause of gastroparesis. The relationship between delayed gastric emptying and symptoms is variable, and individuals with delayed gastric emptying may be asymptomatic. Cross-sectional studies show that around $30 \%-50 \%$ of those with type 1 and 2 diabetes exhibit delayed gastric emptying.,3 Paradoxically, however, in the early stages of 
type 2 diabetes, there may be an accelerated phase of gastric emptying and enhanced proximal contraction resulting in nausea in individuals without overt neuropathy. ${ }^{5,6}$ DG is a cause of significant morbidity in the form of recurrent nausea and vomiting in only a small minority of patients, whilst in others it may manifest simply as unpredictable hypo- and hyperglycemia with overall deranged glycemic control. ${ }^{7}$ Thus, the phenomenon of "gastric hypoglycemia" is well documented ${ }^{8,9}$ and may be an important cause of unexplained hypoglycemia in those who are classified as having brittle diabetes. ${ }^{9}$

\section{MECHANISM OF GASTRIC EMPTYING AND THE PATHOGENESIS OF DG}

Normal gastric emptying depends on synchronized tonic actions of the fundus and antrum with inhibition of pyloric and duodenal contractions. ${ }^{10}$ Complex and highly integrated interactions occur between the gastric smooth muscle, myenteric plexus innervated by the vagal nerve, and gastric pacemaker cells (interstitial cells of Cajal [ICC]). ${ }^{11}$ The primary defects leading to abnormal gastric emptying are vagal autonomic neuropathy and probable ICC pathology. ${ }^{12,13}$ Neuropathy with subsequent aberrant postprandial response to hyperglycemia reduces the frequency of antral contractions and causes weak contractions of the proximal stomach. Glucose levels $>140 \mathrm{mg} / \mathrm{dL}(\sim 8 \mathrm{mmol} / \mathrm{L})$ may diminish antral contractions and inhibit migratory motor complex (MMC) activity. ${ }^{7}$ It is the lack of phase 3 of the MMC (during which ingestible solids are emptied into the duodenum) that leads to antral hypomotility in the fasting state, which ultimately leads to accumulation of large ingestible particles or bezoars. There is also excessive and prolonged tonic and phasic contractions of the pylorus, and this with the other mechanical abnormalities leads to delayed gastric emptying.
Dopamine is present in the gastrointestinal tract and inhibits gastrointestinal motility via the suppression of neuronal acetylcholine release by the D2 receptor. ${ }^{14}$ This mechanism has been exploited therapeutically and forms the mainstay for therapeutic strategies using prokinetic agents. Additional alternative mechanisms include the direct effect of acute hyperglycemia causing a significant delay in gastric emptying, ${ }^{15}$ by inducing motor dysfunction; therefore, improvement in glycemia can increase the rate of gastric emptying. ${ }^{16}$ In both healthy subjects and patients with type 1 diabetes, acute changes in glycemia with a lowering of blood glucose has been shown to affect gastric motor function. ${ }^{17,18}$ Even physiological hyperglycemia of $8 \mathrm{mmol} / \mathrm{L}$ in healthy subjects and patients with type 1 diabetes may prolong the gastric emptying time when compared with $\sim 4 \mathrm{mmol} / \mathrm{L}$. This suggests that glycemic control has a major role in gastric motor dysfunction.

Other factors that may play an important role in altering gastric emptying are hyperinsulinemia and insulin resistance, body mass index (BMI), smoking, and gender. ${ }^{19-22}$ The phenomenon of nitric oxide "blunting" may lead to defects in gastric accommodation as evidenced by sildenafil accelerating gastric emptying in experimental studies $^{23}$ and indeed manifesting as an unwanted side effect of nausea in those taking phosphodiesterase type 5 (PDE5) inhibitors for erectile dysfunction. Abnormalities in glucagon homeostasis have also been implicated in the pathogenesis of DG. ${ }^{24,25}$ Iatrogenic exacerbations of gastroparesis by therapies for hyperglycemia may be precipitated by agents that interfere with the neuroendocrine axis. Nausea may occur with metformin and this may well be related to the recently reported effect of metformin inhibiting dipeptidyl peptidase-4 (DPP-4) and raising glucagon-like peptide-1 (GLP-1). ${ }^{26}$ Of course, both nausea and vomiting are common 
with GLP-1 analogs and are the most common causes of therapy failure. ${ }^{24,25,27}$ Alternative diabetic agents that have also been implicated in exacerbating delayed gastric emptying are the amylinomimetic therapies such as pramlintide $^{28,29}$ (Table 1).

\section{DIAGNOSIS}

Although this review concentrates on medical and mechanical therapies, it is important to highlight routine standards of care when diagnosing DG. Other motility disorders can mimic DG, such as gastric outlet obstruction. Use of prokinetic therapy in the latter may significantly exacerbate symptoms and, therefore, it is important to exclude this disorder prior to initiating therapy. An esophagogastroduodenoscopy (EGD) or a barium meal should be performed prior to measurements of gastric emptying by scintigraphy, ${ }^{13} \mathrm{C}$-acetate $/{ }^{13} \mathrm{C}$-octanoate breath test, or the SmartPill ${ }^{\circledR}$ device (SmartPill Inc., Buffalo, NY, USA). Other less commonly used methods include ultrasonography and electrogastrography (mainly for research).

Gastric emptying scintigraphy (GES) is considered the standard for measuring gastric emptying and there has been some progress towards using a single standardized protocol, ${ }^{21,30}$ although this is currently not uniformly accepted. Historically, there have been inconsistencies in meal preparations, patient positioning, frequency, and duration of imaging, hence the normal range of values. ${ }^{21}$ This posed problems in the interpretation and validation of the results, particularly from "outside" institutions. Limitations of other methods exist; breath tests assume normal small bowel and pulmonary function, the SmartPill is not widely available, and ultrasonography is operator dependent and generally only measures liquid emptying. ${ }^{21}$ The suggested standardized test is by scintigraphy, using a low-fat, egg-white meal with imaging at baseline, 1, 2, and 4 hours after ingestion. ${ }^{21}$

\section{MANAGEMENT}

Key principles in the treatment of DG are the correction of exacerbating factors, which include regulation of glycemia, adequate nutritional support, and the use of prokinetic therapies, which have formed the cornerstone of treatment for DG. ${ }^{31}$ The aim of treatment is to alleviate symptoms, shorten gastric emptying time, improve the nutritional status of the

Table 1. Diabetes therapies, the effects on gastric emptying, and mechanism of action.

\begin{tabular}{ll}
\hline Drug & Effect on gastric emptying and mechanism \\
\hline Metformin & $\begin{array}{l}\text { Possibly delayed: due to DPP-4 inhibition (gastric emptying studies required for definitive } \\
\text { assessment) }\end{array}$ \\
Sulfonylureas & None \\
Glitazones & None \\
$\begin{array}{l}\text {-Glucosidase inhibitors } \\
\text { (particularly arcabose) }\end{array}$ & Delayed: probably due to release of gut hormones including GLP-1 and CCK \\
Amylinomimetics & $\begin{array}{l}\text { Delayed: inhibition of vagal cholinergic function } \\
\text { GLP-1 analogs }\end{array}$ \\
& $\begin{array}{l}\text { Delayed: inhibition of vagal cholinergic function and changes in neuroendocrine axis leading to } \\
\text { reduced antroduodenal contractility }\end{array}$ \\
DPP-4 inhibitors & None: presumably because of lower GLP-1 concentrations than in GLP-1 analogs \\
\hline
\end{tabular}

$\mathrm{CCK}=$ cholecystokinin; DPP-4=dipeptidyl peptidase-4; GLP-1=glucagon-like peptide-1. 
patient, and thus optimize glycemic control. As previously discussed, hyperglycemia itself may delay gastric emptying and adequate control of glycemia is recognized as an important facet in the management of DG. However, there is little evidence to indicate that prokinetic agents may improve glycemic control through improved gastric emptying. ${ }^{6}$

\section{PROKINETIC AGENTS}

Prokinetic agents are the mainstay of treatment for DG and their use dates back to the 1970s. ${ }^{32,33}$ However, there is a paucity of longitudinal studies demonstrating long-term effectiveness of prokinetic therapy. In part, this reflects the natural history of DG, which is often characterized by exacerbations and spontaneous remissions which do not require long-term therapy.

\section{Metoclopramide}

The use of metoclopramide has waxed and waned, particularly with the approval and subsequent withdrawal of cisapride. ${ }^{14}$ Of the prokinetic agents, only metoclopramide has been licensed for use by the Food and Drug Administration (FDA) in DG. It is a potent central and peripheral dopamine-receptor (specifically D2 receptor) and to a lesser extent serotonin antagonist ${ }^{34}$ acting on the brain stem and vagal nerves. It is thought to induce acetylcholine release from enteric neurons by antagonism of D2 receptors ${ }^{14}$ increasing antral contractions. ${ }^{35}$ Several clinical trials of metoclopramide have shown it to be an effective short-term therapy in DG ${ }^{32-35}$ although a longer duration of use may be associated with loss of gastrokinetic properties of the drug ${ }^{36}$ but there is a lack of longitudinal data confirming this. Randomized studies of metoclopramide have shown improvement in gastric emptying, ${ }^{37-40}$ but this correlates poorly with symptoms. ${ }^{39-40}$ This poor correlation of symptoms with functional deficits is typical of DG, especially as those with severe symptoms may only have mild-to-moderate impairment of gastric emptying. ${ }^{41}$ Metoclopramide can cross the blood-brain barrier accounting for its significant central nervous system (CNS) side effects, which include anxiety, agitation, somnolence, insomnia, and movement disorders with long-term use, increasing the risk of developing intractable tardive dyskinesia (around 1\%). ${ }^{42}$ Hence surreptitious use of this medication is recommended and it is approved by the FDA for short-term (4-12 weeks) use only. ${ }^{43}$ However, because DG is chronic, it is often prescribed indefinitely on an "as required" basis. Diabetes itself is a risk factor for tardive dyskinesia, along with female sex and younger age; the use of this drug, ${ }^{14}$ further enhances the likelihood of CNS side effects in DG.

\section{Domperidone}

Domperidone is another dopamine (D2)receptor antagonist that antagonizes peripheral receptors, particularly in the stomach, leading to enhanced stomach contraction. ${ }^{11}$ It does not cross the blood-brain barrier and subsequently has a superior side-effect profile to metoclopramide with a lack of CNS effects. ${ }^{4}$ Indeed, a study of metoclopramide versus domperidone by Patterson et al. ${ }^{44}$ showed a significantly reduced CNS side-effect profile with domperidone, with greater tolerability but equal efficacy in improving symptoms. A number of studies over the past two decades have evaluated gastric emptying time, showing an improvement with the use of domperidone. ${ }^{45-49}$ In the systematic review by Sugumar et al. in 2008, ${ }^{49}$ $64 \%$ of studies showed significant efficacy for an improvement of symptoms, 60\% showed an effect on gastric emptying, and $67 \%$ showed that domperidone effectively reduced hospital 
admissions. However, the methodological content of the evaluated studies was poor with a lack of a placebo control group in most studies. ${ }^{49}$ At present, domperidone is not FDA approved for gastroparesis, and obtaining the drug for clinical practice in the US requires an investigational new drug application to the FDA. ${ }^{50}$ Dosing regimens and common side effects of dopamine (D2)-receptor antagonists are detailed in Table 2, along with other prokinetic agents.

\section{Erythromycin and Motilin Receptor Agonists}

Erythromycin is a motilin receptor agonist that is associated with increased antral contractions with improved gastric emptying, ${ }^{11,52}$ particularly when administered intravenously. ${ }^{52}$ Intravenous erythromycin is the drug of choice in relieving acute gastroparesis requiring hospitalization. ${ }^{50-53}$ Dose tolerance may occur with chronic use, ${ }^{51}$ and also due to the interactions with cytochrome P450 CYP3A4 inhibitors, it is not always a suitable therapy. ${ }^{11}$ Other motilin agonists, such as azithromycin and clarithromycin, have been used but because they have not been extensively studied, they may be used only when gastroparesis symptoms are unresponsive to other prokinetics. Investigational motilin agonists, such as mitemcinal (GM-611) and ABT-229, lack the antibiotic activity of other drugs and have been assessed in clinical trials, ${ }^{54-56}$ particularly as antibiotic resistance is considered to be of concern in chronic erythromycin use. ${ }^{57}$ However, ABT-229 has failed to effectively control gastroparesis symptoms in placebo-controlled trials. ${ }^{54,55}$ A study of mitemcinal showed a disparity between gastroparesis symptoms and gastric emptying, as the latter was enhanced without a significant difference in symptom relief between the active compound and placebo. ${ }^{56}$ Mitemcinal may have a future role in the treatment of gastroparesis but requires further clinical trials to evaluate its safety and efficacy.

Table 2. Agents currently used in the treatment of diabetic gastroparesis.

\begin{tabular}{|c|c|c|c|c|}
\hline Class of agent & Name(s) & Route (s) & Dosing & Side effects \\
\hline \multirow[t]{2}{*}{$\begin{array}{l}\text { Dopamine (D2)-receptor } \\
\text { antagonists }\end{array}$} & Metoclopramide & PO, IV, SC, IM & $\begin{array}{l}10 \mathrm{mg} \text { TDS/ } \\
\text { QDS before } \\
\text { meals }\end{array}$ & $\begin{array}{l}\text { Anxiety, depression, extrapyramidal } \\
\text { movement disorders, galactorrhoea, } \\
\text { tardive dyskinesia }\end{array}$ \\
\hline & Domperidone & $\mathrm{PO}$ & $\begin{array}{l}10-20 \mathrm{mg} \text { TDS } \\
\text { before meals }\end{array}$ & $\begin{array}{l}\text { Side effects listed above plus: } \\
\text { abdominal cramps, irregular } \\
\text { menstrual periods, loss of libido }\end{array}$ \\
\hline \multirow[t]{3}{*}{ Motilin-receptor agonists } & Erythromycin & PO, IV & $\begin{array}{l}40-250 \mathrm{mg} \text { TDS } \\
\text { before meals }\end{array}$ & $\begin{array}{l}\text { Abdominal cramping, early satiety, } \\
\text { urticaria, rashes }\end{array}$ \\
\hline & Clarithromycin & $\mathrm{PO}$ & $125-250 \mathrm{mg}$ OD & \\
\hline & Azithromycin & $\mathrm{PO}$ & $250 \mathrm{mg}$ OD & \\
\hline $\begin{array}{l}\text { Acetylcholinesterase } \\
\text { inhibitors }\end{array}$ & Pyridostigmine & $\mathrm{PO}$ & $30 \mathrm{mg}$ QDS & $\begin{array}{l}\text { Sweating, bladder dysfunction, } \\
\text { increased production of saliva, } \\
\text { diaphoresis, muscle weakness }\end{array}$ \\
\hline
\end{tabular}

$\mathrm{IM}=$ intramuscular; $\mathrm{IV}=$ intravenous; $\mathrm{OD}=$ once daily; $\mathrm{PO}=$ oral; $\mathrm{QDS}=$ four times daily; $\mathrm{SC}=$ subcutaneous; TDS=three times daily. 


\section{Cisapride}

Cisapride is a prokinetic agent that acts via $5-\mathrm{HT}_{4}$ receptors enhancing a cholinergic effect and inducing increased motor activity. ${ }^{58}$ Previous studies comparing cisapride to other prokinetic agents have shown equivalent efficacy with both erythromycin and metoclopramide. ${ }^{54,55}$ Indeed, gastric emptying is improved with cisapride administration; ${ }^{59-63}$ however, due to safety concerns related to cardiac dysrhythmias, the drug was withdrawn from the USA ${ }^{14}$ and, subsequently, the UK in 2000. Tegaserod, another $5-\mathrm{HT}_{4}$-receptor agonist used in DG, was again withdrawn due to cardiac safety concerns.

\section{Ghrelin Agonists}

Ghrelin is a recently discovered peptide that stimulates growth hormone release. ${ }^{64-67}$ It is synthesized in endocrine cells in the gastric mucosa ${ }^{61-63}$ and is believed to exert the majority of its actions through the receptor GHSR-1a, ${ }^{68}$ which mediates gastric motility and emptying with the induction of MMC. ${ }^{69}$ Ghrelin administration has been shown to enhance appetite and food intake ${ }^{70,71}$ but other non-DG studies have shown no difference between ghrelin and placebo. ${ }^{72}$ In a randomized, doubleblind, crossover trial of ghrelin in DG by Murray et al., ${ }^{73}$ gastric emptying was increased but did not always favorably improve symptoms, a phenomenon also common to trials with other prokinetic agents. ${ }^{54,56}$ Since the discovery of ghrelin, a number of molecularly similar receptor agonists have been used in clinical trials of gastrointestinal motility disorders. ${ }^{74-76}$ TZP-101 is a selective intravenously administered agonist at the ghrelin receptor site. It appears to have a good safety profile in trials of healthy volunteers, ${ }^{77}$ and has also been shown to be effective in enhancing gastric motility in DG $^{75,76}$ and accelerating recovery in surgical postoperative ileus. ${ }^{74}$ Furthermore, an oral preparation (TZP-102) has been formulated, which is currently in phase 2 clinical trials. These novel ghrelin agonists show promise, particularly in view of the relatively poor side effect profiles of currently licensed prokinetic therapies.

\section{Other Prokinetic Agents}

Other agents include muscarinic agonists and anticholinesterases such as bethanechol and pyridostigmine, respectively, and may be used in DG, but data assessing effects on gastric emptying are lacking..$^{50}$

\section{MECHANICAL THERAPIES}

A number of nonpharmacological treatments have been used with varying success in the management of DG.

\section{Acupuncture}

The underlying mechanism of acupuncture in reducing symptoms of gastroparesis is unknown. ${ }^{10}$ Efficacy has been reported for symptoms in a singleblind, randomized trial of electroacupuncture. ${ }^{78}$ Dyspeptic symptoms were reduced and solid gastric emptying was accelerated. Further studies are required to investigate the possible benefits of acupuncture in DG.

\section{Botulinum Toxin}

Pylorospasm (excessive, prolonged contractions of the pylorus) is recognized as a manifestation of DG and has been investigated with antroduodenal manometry..$^{79,80}$ Botulinum toxin is an inhibitor of neuromuscular 
transmission at cholinergic terminals, ${ }^{81}$ and has been used in achalasia. ${ }^{82}$ Whilst several uncontrolled studies have suggested efficacy, ${ }^{83}$ two previous placebo-controlled trials have not shown superiority of botulinum toxin over placebo in managing DG. ${ }^{84,85}$ Neither study had antroduodenal manometry, particularly considering that small intestine motor dysfunction can range anywhere from 17\% to $85 \%$ in DG. ${ }^{83}$ Botulinum toxin may still be an effective therapy particularly in those with pylorospasm; however, routine use is not recommended at present.

\section{Gastric Pacing}

Recently, gastric electrical stimulation therapy (gastric pacing) has been approved by the FDA (Enterra therapy, Medtronic, Minneapolis, MN, USA). ${ }^{4}$ The National Institute for Health and Clinical Excellence (NICE) advises that gastric electrical stimulation is an option for the treatment of patients with chronic, intractable, drug-refractory nausea and vomiting. ${ }^{86}$ Although patients suitable for this procedure are relatively uncommon, those with severe symptoms may well benefit. ${ }^{86}$ Gastric electrical stimulation delivers impulses at high frequency/low energy (short pulses) at around 12 pulses per minute via a pacemaker. The device is implanted on the anterior abdominal wall and leads are implanted in the serosa of the greater curvature of the stomach. Both the severity and frequency of symptoms improved in open-label studies, which were maintained for up to 4 years. ${ }^{87-91}$ The underlying basis for improved symptoms has again not been consistently related to accelerated gastric emptying. ${ }^{88}$ Central effects and increases in postprandial gastric accommodation have been suggested, but the precise mechanism remains uncertain. Infection is the major complication of this treatment, requiring removal of the device in approximately $10 \%$ of patients.

\section{Surgical Therapies}

Surgical treatments may be used in those with severe intractable DG who are often hospitalized on multiple occasions. Gastrostomy may be used to alleviate severe symptoms such as nausea, vomiting, and bloating, ${ }^{92}$ although persistent symptoms may still exist despite surgery due to small bowel denervation and dysmotility. ${ }^{93}$ Jejunostomies are indicated to maintain fluid balance and nutritional status, ${ }^{92}$ and can be an effective "last resort" measure. ${ }^{92}$ Interestingly, pancreatic transplantation has been shown to benefit those with DG. ${ }^{94}$ Studies assessing neuropathy have shown early nerve fiber regeneration in type 1 diabetic patients after pancreas transplantation, ${ }^{95}$ and this may be the potential basis for relieving symptoms, but of course, overall improved glycemic control must play a role in improving gastric emptying.

\section{CONCLUSION}

The rising prevalence of diabetes will inevitably result in increasing rates of chronic complications including gastroparesis. Patients develop a variety of symptoms that do not always correlate with the degree of abnormality on gastric emptying. Current treatment options are limited; however, novel investigational agents of the motilin and ghrelin class show promise. Intractable DG may require intervention with gastric electrical stimulation or surgery.

\section{ACKNOWLEDGMENTS}

The authors declare that they have no conflicts of interest. 
Open Access. This article is distributed under the terms of the Creative Commons Attribution Noncommercial License which permits any noncommercial use, distribution, and reproduction in any medium, provided the original author(s) and source are credited.

\section{REFERENCES}

1. Bytzer P, Talley NJ, Leemon M, Young LJ, Jones MP, Horowitz M. Prevalence of gastrointestinal symptoms associated with diabetes mellitus: a population-based survey of 15,000 adults. Arch Intern Med. 2001;161:1989-1996.

2. Ricci JA, Siddique R, Stewart WF, Sandler RS, Sloan $S$, Farup CE. Upper gastrointestinal symptoms in a US national sample of adults with diabetes. Scand J Gastroenterol. 2000;35:152-159.

3. Samsom M, Bharucha A, Gerich JE, et al. Diabetes mellitus and gastric emptying: questions and issues in clinical practice. Diabetes Metab Res Rev. 2009;25:502-514.

4. Patrick A, Epstein O. Review article: gastroparesis. Aliment Pharmacol Ther. 2008;27:724-740.

5. Frank JW, Saslow SB, Camilleri M, Thomforde GM, Dinneen S, Rizza RA. Mechanism of accelerated gastric emptying of liquids and hyperglycemia in patients with type II diabetes mellitus. Gastroenterology. 1995;109:755-765.

6. Intagliata N, Koch KL. Gastroparesis in type 2 diabetes mellitus: prevalence, etiology, diagnosis, and treatment. Curr Gastroenterol Rep. 2007;9:270279.

7. Barnett JL, Owyang C. Serum glucose concentration as a modulator of interdigestive gastric motility. Gastroenterology. 1988;94:739-744.

8. Lysy J, Israeli E, Strauss-Liviatan N, Goldin E. Relationships between hypoglycaemia and gastric emptying abnormalities in insulin-treated diabetic patients. Neurogastroenterol Motil. 2006; 18:433-440.

9. Horowitz M, Jones KL, Rayner CK, Read NW. "Gastric" hypoglycaemia - an important concept in diabetes management. Neurogastroenterol Motil. 2006;18:405-407.

10. Ma J, Rayner CK, Jones KL, Horowitz M. Diabetic gastroparesis: diagnosis and management. Drugs. 2009;69:971-986.
11. Hejazi R, McCallum R. Diabetic gastroparesis: a review of medical treatments. Pract Gastroenterol. 2009;6:10-20.

12. Forster J, Damjanov I, Lin Z, Sarosiek I, Wetzel P, McCallum RW. Absence of the interstitial cells of Cajal in patients with gastroparesis and correlation with clinical findings. J Gastrointest Surg. 2005;9:102-108.

13. Lin Z, Sarosiek I, Forster J, Damjanov I, Hou Q, McCallum RW. Association of the status of interstitial cells of Cajal and electrogastrogram parameters, gastric emptying and symptoms in patients with gastroparesis. Neurogastroenterol Motil. 2009;22:56-61.

14. Pasricha PJ, Pehlivanov N, Sugumar A, Jankovic J. Drug insight: from disturbed motility to disordered movement: a review of the clinical benefits and medicolegal risks of metoclopramide. Nat Clin Pract Gastroenterol Hepatol. 2006;3:138-148.

15. Fraser RJ, Horowitz M, Maddox AF, Harding PE, Chatterton BE, Dent J. Hyperglycaemia slows gastric emptying in type 1 (insulin-dependent) diabetes mellitus. Diabetologia. 1990;33:675-680.

16. Sogabe $M$, Okahisa $T$, Tsujigami $K$, et al. Ultrasonographic assessment of gastric motility in diabetic gastroparesis before and after attaining glycemic control. J Gastroenterol. 2005;40: 583-590.

17. Schvarcz E, Palmér $M$, Aman J, Lindkvist $B$, Beckman KW. Hypoglycaemia increases the gastric emptying rate in patients with type 1 diabetes mellitus. Diabetic Med. 1993;10:660-663.

18. Schvarcz E, Palmér $M$, Aman J, Berne C. Hypoglycemia increases the gastric emptying rate in healthy subjects. Diabetes Care. 1995;18: 674-676.

19. Miller G, Palmer KR, Smith B, Ferrington C, Merrick MV. Smoking delays gastric emptying of solids. Gut. 1989;30:50-53.

20. Jones KL, Russo A, Stevens JE, Wishart JM, Berry MK, Horowitz M. Predictors of delayed gastric emptying in diabetes. Diabetes Care. 2001;24: 1264-1269.

21. Abell TL, Camilleri $\mathrm{M}$, Donohoe $\mathrm{K}$, et al. Consensus recommendations for gastric emptying scintigraphy: a joint report of the American Neurogastroenterology and Motility Society and the Society of Nuclear Medicine. J Nucl Med Technol. 2008;36:44-54. 
22. Eliasson B, Björnsson E, Urbanavicius $\mathrm{V}$, et al. Hyperinsulinaemia impairs gastrointestinal motility and slows carbohydrate absorption. Diabetologia. 1995;38:79-85.

23. Watkins CC, Sawa A, Jaffrey S, et al. Insulin restores neuronal nitric oxide synthase expression and function that is lost in diabetic gastropathy. J Clin Invest. 2000;106:373-384.

24. Bunck MC, Diamant M, Cornér A, et al. Oneyear treatment with exenatide improves betacell function, compared with insulin glargine, in metformin-treated type 2 diabetic patients: a randomized, controlled trial. Diabetes Care. 2009;32:762-768.

25. Heine RJ, Van Gaal LF, Johns D, et al. Exenatide versus insulin glargine in patients with suboptimally controlled type 2 diabetes: a randomized trial. Ann Intern Med. 2005;143:559-569.

26. Cuthbertson J, Patterson S, O'Harte FP, Bell PM. Addition of metformin to exogenous glucagonlike peptide- 1 results in increased serum glucagonlike peptide- 1 concentrations and greater glucose lowering in type 2 diabetes mellitus. Metabolism. 2010. In Press.

27. Little TJ, Pilichiewicz AN, Russo A, et al. Effects of intravenous glucagon-like peptide-1 on gastric emptying and intragastric distribution in healthy subjects: relationships with postprandial glycemic and insulinemic responses. J Clin Endocrinol Metab. 2006;91:1916-1923.

28. Vella A, Lee JS, Camilleri $M$, et al. Effects of pramlintide, an amylin analogue, on gastric emptying in type 1 and 2 diabetes mellitus. Neurogastroenterol Motil. 2002;14:123-131.

29. Samsom M, Szarka LA, Camilleri M, Vella A, Zinsmeister AR, Rizza RA. Pramlintide, an amylin analog, selectively delays gastric emptying: potential role of vagal inhibition. Am J Physiol Gastrointest Liver Physiol. 2000;278: 946-951.

30. Koch CA, Uwaifo GI. Are gastrointestinal symptoms related to diabetes mellitus and glycemic control? Eur J Gastroenterol Hepatol. 2008;20:822-825.

31. Heine RJ, Brodows R. Diabetic gastroparesis. N Engl J Med. 2007;357:418-420.

32. Longstreth GF, Malagelada JR, Kelly KA. Metoclopramide stimulation of gastric motility and emptying in diabetic gastroparesis. Ann Intern Med. 1977;86:195-196.
33. Perkel MS, Moore C, Hersh T, Davidson ED. Metoclopramide therapy in patients with delayed gastric emptying: a randomized, double-blind study. Dig Dis Sci. 1979;24:662-666.

34. Peringer E, Jenner $P$, Marsden CD. Effect of metoclopramide on turnover of brain dopamine noradrenaline and 5-hydroxytryptamine. J Pharm Pharmacol. 1975;27:442-444.

35. Koch K. Diabetic gastropathy: gastric neuromuscular dysfunction in diabetes mellitus: a review of symptoms, pathophysiology, and tretment. Dig Dis Sci. 1999;44:1061-1075.

36. Schade RR, Dugas MC, Lhotsky DM, Gavaler JS, Van Thiel DH. Effect of metoclopramide on gastric liquid emptying in patients with diabetic gastroparesis. Dig Dis Sci. 1985;30:10-15.

37. Erbas T, Varoglu E, Erbas B, Tastekin G, Akalin S. Comparison of metoclopramide and erythromycin in the treatment of diabetic gastroparesis. Diabetes Care. 1993;16:1511-1514.

38. McCallum RW, Ricci DA, Rakatansky $\mathrm{H}$, et al. A multicenter placebo-controlled clinical trial of oral metoclopramide in diabetic gastroparesis. Diabetes Care. 1983;6:463-467.

39. Ricci DA, Saltzman MB, Meyer C, Callachan C, McCallum RW. Effect of metoclopramide in diabetic gastroparesis. J Clin Gastroenterol. 1985;7:25-32.

40. Snape WJ Jr., Battle WM, Schwartz SS, Braunstein $\mathrm{SN}$, Goldstein HA, Alavi A. Metoclopramide to treat gastroparesis due to diabetes mellitus. Ann Intern Med. 1982;96:444-446.

41. Talley N. Diabetic gastropathy and prokinetics. Am J Gastroenterol. 2003;98:264-271.

42. Tonini M., Cipolina L, Poluuzzi E, et al. Clinical implications of enteric and central D2 receptor blockade by antidopaminergic gastrointestinal prokinetics. Aliment Pharmacol Ther. 2004;19:379-390.

43. Parkman HP. American Gastroenterological Association technical review on the diagnosis and treatment of gastroparesis. Gastroenterology. 2004;127:1592-1622.

44. Patterson D, Abell T, Rothstein R, Koch K, Barnett J. A double-blind multicenter comparison of domperidone and metoclopramide in the treatment of diabetic patients with symptoms of gastroparesis. Am J Gastroenterol. 1999;94:12301234. 
45. Farup CE, Leidy NK, Murray M, Williams GR, Helbers L, Quigley EM. Effect of domperidone on the health-related quality of life of patients with symptoms of diabetic gastroparesis. Diabetes Care. 1998;21:1699-1706.

46. Heer M, Müller-Duysing W, Benes I, et al. Diabetic gastroparesis: treatment with domperidone - a double-blind, placebo-controlled trial. Digestion. 1983;27:214-217.

47. Champion EA. Domperidone (Motilium) improves symptoms and solid phase gastric emptying in diabetic gastroparesis. Gastroenterol. 1987;82:975.

48. Dumitrascu DL, Weinbeck M. Domperidone versus metoclopramide in the treatment of diabetic gastroparesis. Am J Gastroenterol. 2000;95: 316-317.

49. Sugumar A, Singh A, Pasricha PJ. A systematic review of the efficacy of domperidone for the treatment of diabetic gastroparesis. Clin Gastroenterol Hepatol. 2008;6:726-733.

50. Camilleri M. Clinical practice. Diabetic gastroparesis. N Engl J Med. 2007;356:820-829.

51. Richards RD, Davenport K, McCallum RW. The treatment of idiopathic and diabetic gastroparesis with acute intravenous and chronic oral erythromycin. Am J Gastroenterol. 1993;88: 203-207.

52. Janssens J, Peeters TL, Vantrappen G. Improvement of gastric emptying in diabetic gastroparesis by erythromycin. Preliminary studies. N Engl J Med. 1990;322:1028-1031.

53. Dive A, Miesse C, Galanti L, et al. Effect of erythromycin on gastric motility in mechanically ventilated critically ill patients: a double-blind, randomized, placebo-controlled study. Crit Care Med. 1995;23:1356-1362.

54. Talley NJ, Verlinden M, Geenen DJ, et al. Effects of a motilin receptor agonist (ABT-229) on upper gastrointestinal symptoms in type 1 diabetes mellitus: a randomised, double blind, placebo controlled trial. Gut. 2001;49:395-401.

55. Talley NJ, Verlinden M, Snape W, et al. Failure of a motilin receptor agonist (ABT-229) to relieve the symptoms of functional dyspepsia in patients with and without delayed gastric emptying: a randomized double-blind placebocontrolled trial. Aliment Pharmacol Ther. 2000;14:1653-1661.
56. McCallum RW, Cynshi O. Clinical trial: effect of mitemcinal (a motilin agonist) on gastric emptying in patients with gastroparesis - a randomized, multicentre, placebo-controlled study. Aliment Pharmacol Ther. 2007;26: 1121-1130.

57. Hawkyard CV, Koerner RJ. The use of erythromycin as a gastrointestinal prokinetic agent in adult critical care: benefits versus risks. J Antimicrob Chemother. 2007;59:347-358.

58. McCallum RW, Prakash C, Campoli-Richards DM, Goa KL. Cisapride. A preliminary review of its pharmacodynamic and pharmacokinetic properties, and therapeutic use as a prokinetic agent in gastrointestinal disorders. Drugs. 1988;36:652-681.

59. Champion MC. Management of idiopathic, diabetic and miscellaneous gastroparesis with cisapride. Scand J Gastroenterol Suppl. 1989;165:44-52. Discussion:52-53.

60. Horowitz M, Maddern GJ, Maddox A, Wishart J, Chatterton BE, Shearman DJ. Effects of cisapride on gastric and esophageal emptying in progressive systemic sclerosis. Gastroenterology. 1987;93: 311-315.

61. Horowitz M, Maddox A, Harding PE, et al. Effect of cisapride on gastric and esophageal emptying in insulin-dependent diabetes mellitus. Gastroenterology. 1987;92:1899-1907.

62. McHugh S, Lico S, Diamant NE. Cisapride vs. metoclopramide. Dig Dis Sci. 1992;37:997-1001.

63. Havelund T, Oster-Jørgensen E, Eshøj O, Larsen ML, Lauritsen K. Effects of cisapride on gastroparesis in patients with insulin-dependent diabetes mellitus. Acta Medica Scandinavica. 1987;222:339-343.

64. Takaya K, Ariyasu H, Kanamoto N, et al. Ghrelin strongly stimulates growth hormone release in humans. J Clin Endocrinol Metab. 2000;85: 4908-4911.

65. Peino R, Baldelli R, Rodriguez-Garcia J, et al. Ghrelin-induced growth hormone secretion in humans. Eur J Endocrinol. 2000;143:R11-R14.

66. Date $\mathrm{Y}$, Kojima M, Hosoda $\mathrm{H}$, et al. Ghrelin, a novel growth hormone-releasing acylated peptide, is synthesized in a distinct endocrine cell type in the gastrointestinal tracts of rats and humans. Endocrinology. 2000;141:4255-4261.

67. Kojima M, Hosoda H, Date Y, Nakazato M, Matsuo $\mathrm{H}$, Kangawa K. Ghrelin is a growth-hormone- 
releasing acylated peptide from stomach. Nature. 1999;402:656-660.

68. Howard AD, Feighner SD, Cully DF, et al. A receptor in pituitary and hypothalamus that functions in growth hormone release. Science. 1996;273:974977.

69. Tack J, Depoortere I, Bisschops R, et al. Influence of ghrelin on interdigestive gastrointestinal motility in humans. Gut. 2006;55:327-333.

70. Wren AM, Seal LJ, Cohen MA, et al. Ghrelin enhances appetite and increases food intake in humans. J Clin Endocrinol Metab. 2001;86:5992.

71. Druce MR. Ghrelin increases food intake in obese as well as lean subjects. Int J Obes (Lond). 2005;29:1130-1136.

72. Strasser F, Lutz TA, Maeder MT, et al. Safety, tolerability and pharmacokinetics of intravenous ghrelin for cancer-related anorexia/cachexia: a randomised, placebo-controlled, double-blind, double-crossover study. $\mathrm{Br} J$ Cancer. 2008;98: 300-308.

73. Murray CD, Martin NM, Patterson M, et al. Ghrelin enhances gastric emptying in diabetic gastroparesis: a double blind, placebo controlled, crossover study. Gut. 2005;54:1693-1698.

74. Popescu I, Fleshner PR, Pezzullo JC, Charlton PA, Kosutic G, Senagore AJ. The Ghrelin agonist TZP101 for management of postoperative ileus after partial colectomy: a randomized, dose-ranging, placebo-controlled clinical trial. Dis Colon Rectum. 2010;53:126-134.

75. Ejskjaer N, Dimcevski G, Wo J, et al. Safety and efficacy of ghrelin agonist TZP-101 in relieving symptoms in patients with diabetic gastroparesis: a randomized, placebo-controlled study. Neurogastroenterol Motil. 2010. In press.

76. Ejskjaer N, Vestergaard ET, Hellström PM, et al. Ghrelin receptor agonist (TZP-101) accelerates gastric emptying in adults with diabetes and symptomatic gastroparesis. Aliment Pharmacol Ther. 2009;29:1179-1187.

77. Lasseter KC, Shaughnessy L, Cummings D, et al. Ghrelin agonist (TZP-101): safety, pharmacokinetics and pharmacodynamic evaluation in healthy volunteers: a phase I, first-in-human study. J Clin Pharmacol. 2008;48:193-202.

78. Wang CP, Kao CH, Chen WK, Lo WY, Hsieh CL. A single-blinded, randomized pilot study evaluating effects of electroacupuncture in diabetic patients with symptoms suggestive of gastroparesis. J Altern Complement Med. 2008;14:833-839.

79. Mearin F, Camilleri M, Malagelada JR. Pyloric dysfunction in diabetics with recurrent nausea and vomiting. Gastroenterology. 1986;90:1919-1925.

80. Camilleri M, Brown ML, Malagelada JR. Relationship between impaired gastric emptying and abnormal gastrointestinal motility. Gastroenterology. 1986;91:94-99.

81. Jankovic J, Brin MF. Therapeutic uses of botulinum toxin. N Engl J Med. 1991;324:1186-1194.

82. Pehlivanov N, Pasricha PJ. Achalasia: botox, dilatation or laparoscopic surgery in 2006. Neurogastroenterol Motil. 2006;18:799-804.

83. Park MI, Camilleri M. Gastroparesis: clinical update. Am J Gastroenterol 2006;101:1129-1139.

84. Arts J, Holvoet L, Caenepeel P, et al. Clinical trial: a randomized-controlled crossover study of intrapyloric injection of botulinum toxin in gastroparesis. Aliment Pharmacol Ther. 2007;26:1251-1258.

85. Friedenberg FK, Palit A, Parkman HP, Hanlon A, Nelson DB. Botulinum toxin A for the treatment of delayed gastric emptying. Am J Gastroenterol. 2008;103:416-423.

86. NICE. Interventional procedure overview: gastroelectrical stimulation for gastroparesis. Clinical guidelines. October 12, 2004. Available at http://www.nice.org.uk/nicemedia/live/11130/ 31200/31200.pdf. Accessed July 16, 2006.

87. Anand C, Al-Juburi A, Familoni B, et al. Gastric electrical stimulation is safe and effective: a long-term study in patients with drug-refractory gastroparesis in three regional centers. Digestion. 2007;75:83-89.

88. Abell TL, Malinowski S, Minocha A. Nutrition aspects of gastroparesis and therapies for drugrefractory patients. Nutr Clin Pract. 2006;21:23-33.

89. Cutts TF, Luo J, Starkebaum W, Rashed H, Abell TL. Is gastric electrical stimulation superior to standard pharmacologic therapy in improving GI symptoms, healthcare resources, and long-term health care benefits? Neurogastroenterol Motil. 2005;17:35-43.

90. Maranki J, Parkman HP. Gastric electric stimulation for the treatment of gastroparesis. Curr Gastroenterol Rep. 2007;9:286-294. 
91. Maranki JL, Lytes V, Meilahn JE, et al. Predictive factors for clinical improvement with Enterra gastric electric stimulation treatment for refractory gastroparesis. Dig Dis Sci. 2008;53:2072-2078.

92. Jones MP, Maganti K. A systematic review of surgical therapy for gastroparesis. Am J Gastroenterol. 2003;98:2122-2129.

93. Camilleri M, Malagelada JR. Abnormal intestinal motility in diabetics with the gastroparesis syndrome. Eur J Clin Invest. 1984;14:420-427.
94. Cashion AK, Holmes SL, Hathaway DK, Gaber AO. Gastroparesis following kidney pancreas transplant. Clin Transplant. 2004;18:306-311.

95. Mehra S, Tavakoli M, Kallinikos PA, et al. Corneal confocal microscopy detects early nerve regeneration after pancreas transplantation in patients with type 1 diabetes. Diabetes Care. 2007;30:2608-2612. 